\title{
Integration of Membrane Processes into Bioconversions
}




\section{Integration of Membrane Processes into Bioconversions}

Edited by

Katalin Bélafi-Bakó

László Gubicza

Research Institute for Chemical and Process Engineering

Kaposvár University

Veszprém. Hungary

and

Marcel Mulder

University of Twente

Enschede. The Netherlands

Springer Science+Business Media, LLC 


\section{Library of Congress Cataloging-in-Publication Data}

Integration of membrane processes into bioconversions / edited by Katalin Bélafi-Bakó, László Gubicza, and Marcel Mulder.

p. cm.

Includes bibliographical references and index.

ISBN 978-1-4613-6917-2 ISBN 978-1-4615-4269-8 (eBook)

DOI 10.1007/978-1-4615-4269-8

1. Membrane separation--Congresses. 2. Bioreactors--Congresses. 3. Membrane filters--Congresses. 4. Membranes (Technology)--Congresses. I. Bélafi-Bakó, Katalin. II. Gubicza, László. III. Mulder, Marcel, 1951-

TP248.25.M46 I55 2000

660.6--dc21

00-042338

Proceedings of the European Membrane Society XVI Annual Summer School on Integration of Membrane Processes into Bioconversions, held August 22-27, 1999, in Veszprém, Hungary

ISBN 978-1-4613-6917-2

(C) 2000 Springer Science+Business Media New York

Originally published by Kluwer Academic/Plenum Publishers in 2000

Softcover reprint of the hardcover 1st edition 2000

http://www.wkap.nl/

$\begin{array}{llllllllll}10 & 9 & 8 & 7 & 6 & 5 & 4 & 3 & 2 & 1\end{array}$

A C.I.P. record for this book is available from the Library of Congress

All rights reserved

No part of this book may be reproduced, stored in a retrieval system, or transmitted in any form or by any means, electronic, mechanical, photocopying, microfilming, recording, or otherwise, without written permission from the Publisher 


\section{PREFACE}

It started during a coffee break at Twente University (Enschede, The Netherlands) during the Euro-Membrane conference in 1997. I was discussing with Dr. Stefan Schlosser (Technical University of Bratislava, Slovakia) and Dr. Marcel Mulder (University of Twente, Enschede, The Netherlands) the fact that the annual Summer Schools of the European Membrane Society (EMS) had been arranged exclusively in Western European countries in the former decade. We felt it was high time to move it somewhere in Central or Eastern Europe. It also turned out that no Summer School had previously been organised in Hungary. So I volunteered Hungary and myself for the 1999 Summer School.

Stefan took me seriously and having been elected as a member of the Council of the EMS, he supported my idea very much. During the Annual Hungarian Membrane Conference (Tata, October, 1998) Stefan visited me to elaborate upon this idea and to build a program outline together with possible lecturers. Joint application of membrane processes and bioconversions was chosen as the subject of the Summer School.

It was apparent that we needed a reliable financial plan in addition to the good scientific program. So, a colleague, and friend of mine, Dr. László Gubicza, senior research engineer and financial expert, was involved in the preliminary work. In November, Marcel Mulder visited our institute to help us, and after three days everything was clear. Both the scientific and financial plans were submitted to the EMS - taking into account the suggestions and advice of Prof. John Howell (President of EMS, University of Bath, United Kingdom) - and our proposal was officially accepted.

The procedure began; the events were accelerating; we started to cope with the tasks: inviting the lecturers, including Hungarians, too; preparing the first circular; looking for sponsors, exhibitors; arranging accommodation/full services; organising social programs, etc. As we began to collect the scientific material from the lecturers during the spring of 1999, Kluwer Academic/Plenum Publishers approached us to ask us to edit the papers into a book. We were happy to do this and this volume is the result, with the title being the same as the Summer School's eventual title, "Integration of membrane processes into bioconversions". 
When Prof. Marianne Nyström (Lappeenranta University of Technology, Finland), council member of the EMS with responsibility for the annual Summer Schools, visited us in May, she was satisfied with the preparations. What we still needed was some marketing and advertising and the EMS council helped a lot. We thank them for that.

The Summer School in August 1999 lasted 5 days in Veszprém, a nice small city on the Northern part of Lake Balaton, and most of the participants and lecturers were impressed "by the friendly, creative and scientific atmosphere and the extraordinary well-designed programme" (as decribed by Prof. Rolf Kümmel, Fraunhofer UMSICHT, Oberhausen, Germany). The organisers believe it was not only due to the huge amount of preliminary work, but the experience obtained attending other conferences, and even from working as a hobby guide, as László Gubicza did.

After the Summer School, the editing work began; collecting and formatting all the selected papers, which were finally sorted into three parts: Fundamentals of membrane processes (i), Basics of bioengineering (ii) and the Integration possibilities of the two fields (iii). The content was provided mainly from the lectures, but much work was required to produce the final book. On behalf of the editors I gratefully acknowledge the valuable cooperation of all the contributors to this book. I wish to express our appreciation to Ms Alison M. Glucksnis (currently Fulbright fellow, National Institute for Environmental Studies, Tsukuba, Japan), Mr. István Rohonyi (Veszprém University, Hungary) and Prof. Colin Webb (UMIST, Manchester, United Kingdom) for correcting the English, and to Miss Joanna Lawrence (Kluwer Academic/Plenum Publishers, London, United Kingdom), Ms Greet van der Voort-Kamminga (University of Twente, Enschede, The Netherlands), Ms Teréz Kanyár and Ms Olga Ulbert (Research Institute of Chemical and Process Engineering, Veszprém, Hungary) for helping us in the administrative and organisational work during the editing of the manuscript. Last but not least, let me express my grateful thanks to my friends, for their work, the two other editors: Dr. László Gubicza and Dr. Marcel Mulder. 


\section{CONTENTS}

\section{Part I}

Fundamentals of membrane processes

Membrane separation processes: General introduction

Bélafi-Bakó, $K$

Transport phenomena in membrane separations

Kümmel, $R$.

What makes filtration with membranes so fascinating?

Basics of microfiltration, ultrafiltration, nanofiltration and reverse osmosis

Staude, E.

Fundamentals of gas separation, vapour permeation and pervaporation

Mulder, M.H.V.

Membrane based processes with immobilised interfaces

Schlosser, $S$.

Pertraction through liquid and polymeric membranes

Schlosser, $S$.

\section{Part II}

Introduction to biochemical engineering

Enzyme catalysed reactions

Giorno, $L$.

Bioreactor design using living cells or organisms

Howell, J.A. 


\section{Part III}

Integration of membrane processes and bioconversions

Biocatalysts and membranes

Bélafi-Bakó, K., Gubicza, L.

Application of membrane processes in food technologies

Kümmel, R., Robert, J.

Nanofiltration application in food technology and environmental protection

Vatai, $G$.

Wine filtration by ceramic membranes

Békássy-Molnár, E.

Extraction of aromas from active fermentation reactors by pervaporation

Schäfer, T., Crespo, J.G.

Membrane bioreactors

Giorno, L.

Monitoring of membrane bioreactors

Wolf, G., Almeida, J., Reis, M.A., Crespo. J.G.

Diffusion mass transfer in enzyme-membrane reactor

Nagy, $E$.

Membrane fermentors

Karaffa, $L$.

Application of immersed membrane bioreactor for food industry effluent treatment

Kicsi, $G$.

Index 


\section{Integration of Membrane \\ Processes into Bioconversions}

